\title{
Kontra Propaganda Deklarasi Negara Papua Barat dalam Konstruksi Pemberitaan Tempo.co
}

\author{
Raden Wahyu Utomo Martianto dan Muhamad Isnaini \\ Fakultas Ilmu Komunikasi, Universitas Budi Luhur \\ martianto.utomo@gmail.com
}

\begin{abstract}
ULMWP Chairperson Benny Wenda unilaterally declared the State Declaration of West Papua on December 1, 2020 from his exile in England, and at the same time appointed himself as President of the Provisional Government of West Papua. The declaration was claimed to be a step forward towards a referendum on Papuan independence to separate itself from the Republic of Indonesia. A number of circles from within Indonesia viewed the declaration as propaganda by the ULMWP and Benny Wenda in their efforts to form global opinion. Resistance emerged in the news from various online and conventional mass media, one of which was the online news media Tempo.co. This study discusses the news framing of the West Papua State Declaration by Tempo.co, to explain how the constructed news text represents counter-propaganda. This qualitative research uses the Robert $N$. Entman framing analysis method by emphasizing, selecting issues or highlighting aspects in a certain reality, which reveal how news framing is carried out by the online media Tempo.co. The research results show that the online media framing of Tempo.co against the West Papua State Declaration is a negative framing, Counter Propaganda is constructed from media text framing which confirms Papua's status as part of Indonesia as the only entity that controls Papua protected by international law. The researcher also found that the Counter-Propaganda at Tempo.co Media Construction in this study, at the same time, is also a form of propaganda from the media itself in expressing the political stance of the media.
\end{abstract}

Keywords: framing; media construction; online media; propaganda; West Papua Declaration

\begin{abstract}
Abstrak
Ketua ULMWP Benny Wenda mendeklarasikan Deklarasi Negara Papua Barat secara sepihak pada 1 Desember 2020 dari pengasingannya di Inggris, sekaligus mengangkat dirinya sebagai Presiden Pemerintah Sementara Papua Barat. Deklarasi tersebut diklaim sebagai langkah maju menuju referandum kemerdekaan Papua untuk memisahkan diri dari NKRI. Sejumlah kalangan dari dalam negeri Indonesia menilai deklarasi tersebut sebagai propaganda ULMWP dan Benny Wenda dalam upayanya untuk membentuk opini global. Perlawanan muncul dalam pemberitaan di berbagai media massa online maupun konvensional, salah satunya adalah media berita online Tempo.co. Kajian ini membahas framing berita Deklarasi Negara Papua Barat oleh media berita online Tempo. co, untuk menjelaskan bagaimana teks berita yang dikonstruksi merepresentasikan kontra-propaganda. Penelitian ini bersifat kualitatif dengan metode analisis framing Robert N. Entman dengan menekankan, memilih isu atau menyoroti aspek-aspek dalam suatu realitas tertentu, yang mengungkap bagaimana framing berita dilakukan oleh media online Tempo.co. Hasil penelitian menunjukkan bahwa pembingkaian media online Tempo.co terhadap Deklarasi Negara Papua Barat merupakan pembingkaian negatif, Kontra Propaganda dikonstruksi dari framing teks media yang menegaskan Papua berstatus bagian dari Indonesia sebagai satu-satunya entitas yang menguasai Papua dilindungi oleh hukum internasional. Peneliti juga menemukan bahwa Kontra Propaganda pada Konstruksi Media Tempo.co dalam penelitian ini, sekaligus juga menjadi bentuk propaganda dari media itu sendiri dalam mengungkapkan keberpihakan atau sikap politik media.
\end{abstract}

Kata Kunci: Deklarasi Papua Barat; framing; konstruksi media; media online; propaganda

Korespondensi: Raden Wahyu Utomo Martianto, S.I.Kom, Fakultas Ilmu Komunikasi Universitas Budi Luhur, Jl. Ciledug Raya No. 99, Jakarta Selatan, DKI Jakarta, 12260 , Email: martianto.utomo@gmail.com

Menyerahkan: Januari 2021, Diterima: April 2021, Terbit: Juli 2021

ISSN: 2549-0559 (cetak), ISSN: 2549-1946 (online), Website: http://jurnal.unpad.ac.id/kajian-jurnalisme 
Volume 05 Nomor 01 Tahun 2021

DOI: $10.24198 / j k j . v 5 i 1.31885$

\section{PENDAHULUAN}

Sejak Indonesia berhasil merebut Papua dari Belanda pada tahun 1963 permasalahan mengenai separatis di Papua terus merongrong kedaulatan Indonesia di bumi Cendrawasih tersebut. Munculnya separatisme Gerakan Papua Merdeka adalah reaksi dari beberapa hal. Pertama, kekecewaan sejarah saat proses integrasi ke Indonesia. Kedua, pihak elit Papua yang merasa tereksklusi dari persaingan dengan para pejabat pusat Indonesia sejak zaman Belanda. Ketiga, pembangunan dan komposisi perangkat daerah yang timpang mengakibatkan opresi dan marginalisasi bagi penduduk Papua. Keempat, banyak pendatang yang kemudian mendominasi dalam bidang politik dan ekonomi sehingga semakin memperdalam marginalisasi suku mereka, kesenjangan ekonomi dan sosial, serta operasi-operasi militer dari Pemerintah Pusat dalam meredam separatisme yang berakibat pada pelanggaran Hak Asasi Manusia (Ilmar, 2017). Respon pemerintah inilah yang kemudian menjadi alat propaganda Organisasi Papua Merdeka (OPM) dalam melobi masyarakat internasional sesuai dengan rekomendasi Kongres Rakyat Papua II dan didukung oleh beberapa negara di kawasan Pasifik Selatan yang tergabung dalam Melanesia Spearhead Group (MSG), sebuah organisasi sub regional wilayah Pasifik Selatan yang identik dengan ras Melanesia yang mana Indonesia juga merupakan salah satu anggotanya (Putra, Legionosuko, \& Madjid, 2019).

Internasionalisasi isu Papua Merdeka dilakukan melalui berbagai forum internasional, publikasi di berbagai media internasional yang berbicara tentang pelanggaran Hak asasi Manusia (Sabir, 2018). Contohnya, reuters.com yang kerap membingkai pemberitaannya sebagai isu sosial, dengan diskriminisasi dan kekerasan pemerintah Indonesia dalam menangani kerusuhan di Papua tahun 2019 menjadi aspek yang ditonjolkan (Widyaningsih \& Lestari, 2020). Kemudian di era digital saat ini propaganda melalui akun-akun media sosial juga digencarkan, seperti akun @ppk.nrwp di media sosial facebook, dan akun kampanye politik@freewestpapua di twitter menjadi salah satu corong utama perjuangan OPM. Menurut hasil Social Network Analysis yang dikeluarkan platform analisis media daring berbasis big data 'Drone Emprit Academic' melalui publikasi berjudul Tiadanya Kontra Narasi Internasional Tentang "West Papua” pada tanggal 1 September 2019 di dunia internasional, hampir seluruh mention dan retweet tentang "West Papua" didominasi oleh cluster Pro West Papua (Fahmi, 2019), menunjukkan bahwa gencarnya propaganda internasionalisasi isu Papua Merdeka melalui media sosial.

Propaganda internasionalisasi isu di media online terkesan tidak mendapatkan perhatian serius dari pemerintah Indonesia, dibiarkan berkembang, dan terbukti pada tanggal 1 Desember 2020 Ketua United Liberation Movement for West Papua (ULMWP), Benny Wenda, berani mengumumkan Deklarasi Negara Papua Barat dari domisilinya di Inggris, di mana bersamaan dengan itu Benny Wenda mengklaim dirinya sebagai Presiden dari pemerintahan sementara Negara Republik Papua Barat. Benny Wenda adalah tokoh pro-kemerdekaan Papua yang sempat ditahan terkait demonstrasi pro-kemerdekaan Papua dengan pengibaran bendera bintang kejora pada tahun 2002. Akan tetapi Benny kabur dari penjara lalu tinggal di Inggris sejak 2003 yang saat itu ia menerima political asylum dari pemerintah Inggris (Mansyur, 2020). Bahwa deklarasi tersebut dilakukan bukan di tanah Papua, melainkan dari Inggris menunjukkan bahwa ULMWP berusaha membentuk opini global terkait Papua Merdeka demi mendapatkan dukungan internasional.

Deklarasi Negara Papua Barat banyak mendapat sorotan media online asing yang turut memberitakan dengan judul yang provokatif mendukung kemerdekaan Papua Barat. Contoh di antaranya, media Inggris reuters.com dengan judul berita "Papuans rally for independence from Indonesia as group declares government in exile" (edisi 1 Desember 2020), media Australia abc.net.au judul berita "West Papuan separatists declare provisional government, 
tell Indonesia to leave the region" (edisi 1 Desember 2020), dan time.com berjudul "A Racial Justice Campaign Brought New Attention to Indonesia's Poorest Region. Will it Translate to Support for Independence?" (edisi 15 Desember 2020) yang dalam isi tulisannya semua menilai bahwa Deklarasi Pemerintahan Sementara Papua Barat merupakan sebuah langkah maju dalam perjuangan rakyat Papua untuk merdeka.

Sebaliknya dengan pemberitaan di media online dalam negeri, di mana banyak yang menunjukkan kontra terhadap propaganda yang dilakukan Benny Wenda melalui Deklarasi Negara Papua Barat. Respon yang beragam kemudian muncul terhadap Deklarasi Negara Papua Barat dari dalam negeri yang diliput di banyak media. Ketua MPR, Bambang Soesatyo, dalam keterangannya yang dikutip dari Antara pada tanggal 3 Desember 2020 menegaskan bahwa klaim deklarasi kemerdekaan Papua Barat yang dikemukakan Benny Wenda mengatasnamakan Gerakan Persatuan Pembebasan Papua Barat, serta penunjukan dirinya sebagai Presiden sementara Papua Barat, merupakan tindakan agitasi dan propaganda, dan pemerintah harus mengambil langkah penegakan hukum yang tegas terhadap Benny Wenda. Respon tersebut mengidentifikasi bahwa Deklarasi Pemerintahan Sementara Papua Barat merupakan sebuah bentuk propaganda untuk mendapatkan perhatian media internasional.

Pro dan kontra dalam berbagai media berita baik online maupun konvensional menunjukkan kemampuan media dalam memilih, menentukan, dan mendefinisikan peristiwa dan sumber berita (Muslim, 2013). Melalui pemberitaan terjadi pembingkaian (framing) oleh media sehingga bingkai peristiwa tersebut yang dikonsumsi dan dipahami masyarakat. Sehingga masyarakat membaca peristiwa yang fakta-faktanya sudah terseleksi, diformat, diberi struktur, dan sesuai dengan perspektif media, dengan demikian dapat dipahami bahwa pemberitaan tentang suatu peristiwa tergantung pada bagaimana media mengonstruksinya (Rubiwati, 2018).

Framing media adalah upaya pembelokkan atau pengalihan fakta secara halus dengan menyeleksi sudut pandang yang digunakan (Alam, 2020). Ketika pilihan sudah dijatuhkan media terhadap aspek tertentu dari suatu isu/peristiwa maka dalam menuliskan aspek tersebut media memilih unsur mana yang ditekankan/ditonjolkan, lalu unsur mana yang perlu disamarkan/dikaburkan dengan mengubah arti/makna kalimat, menambahkan simbol, tanda, citra atau gambar tertentu untuk menyamarkan fakta berita (Launa, 2020). Dengan kemampuan tersebut media acapkali berfungsi sebagai alat propaganda untuk mencapai tujuan atau ambisi dari kepentingan politik. Propaganda dapat dikategorikan sebagai kampanye politik yang merupakan upaya dengan sengaja mengajak dan mengarahkan untuk menanamkan pengaruh, bujukan, atau mempersuasif khalayak agar dapat menerima pandangan, nilai, maupun ideologi dari propagandis (Alfiyani, 2018).

Hardley Cantrill dan Edward A. Filene mendirikan The Institue Of Propaganda pada tahun 1937. Institusi ini menerbitkan beberapa buku dengan buku yang terkenal yaitu, The Fine Art of Propaganda (1939). Dalam buku tersebut terdapat penjabaran tujuh teknik propaganda yaitu Name Calling (Mempermalukan sebuah ide sehingga publik membenci lawan dengan membabi buta), Glittering Generalities (Mengaitkan sebuah ide dengan kata-kata yang memiliki makna baik, membuat publik menganggap ide tersebut baik), Transfer (Mengambil simbol utama dan mengaitkannya dengan gagasan yang lebih kecil, sehingga lebih mudah diterima), Testimonial (Menggunakan penyataan orang yang lebih kredibel untuk mendukung gagasan), Plain folks (Mengaitkan sebuah ide dengan publik, untuk memberi kesan bahwa ide tersebut adalah bagian dari mereka), Card Stacking (Mengurasi fakta untuk mencapai efek tertentu), Bandwagon Effect (Hal yang dipropagandakan digembar-gemborkan sebagai sesuatu yang populer, sukses, didukung mayoritas) (Aditya \& Sukendro, 2020).

Media dewasa ini kerap digunakan sebagai sarana untuk menyebarkan pesan politik atau 
ideologi dalam masyarakat. Informasi yang disajikan dalam pemberitaan media sangat mungkin dipengaruhi oleh ideologi tertentu dan terbuka untuk propaganda. Di era digital saat ini media online merupakan media yang efektif dalam melakukan propaganda politik dibandingkan dengan menggunakan media konvensional. Karena selain pesan propaganda dapat diproduksi dalam bentuk gambar maupun narasi yang menarik perhatian pembaca, juga pembaca tidak membutuhkan waktu yang lama untuk membaca atau mengartikan pesan yang disampaikan (Tahir, Kusmanto, \& Amin, 2020). Namun sebaliknya media juga dapat menjadi alat untuk melawan propaganda, ketika bertentangan dengan ideologi yang dianut oleh media tersebut.

Seperti yang telah dipaparkan sebelumnya Deklarasi Negara Papua Merdeka oleh ULMWP dan Benny Wenda diklaim sebagai bentuk propaganda untuk memisahkan diri dari NKRI. Propaganda bertujuan untuk memengaruhi pola pikir, imajinasi, dan opini khalayak dalam julah besar dalam bentuk kesadaran, tuntutan balasan, tanggapan yang akan melahirkan perubahan. Ruang lingkup target khalayak yang begitu besar, maka media massa terutama yang pro-NKRI berperan menghadapinya. Jurnalis harus mampu mendeteksi propaganda dengan segala cara untuk menyembunyikan transmisi dan penyebaran propaganda tersebut (kontra propaganda) dalam konstruksi pemberitaannya.

Perkembangan media dewasa ini tak dapat dihindari di mana khalayak lebih banyak menggali informasi dari media online. Salah satu karakter media online dalam mendistribusikan beritanya adalah immediacy, yaitu bagiamana dalam jurnalistik online informasi dapat disampaikan dengan singkat, langsung dan cepat (Lestari, 2017). Cara ini mengesankan seolah pemberitaan media online tidak mendalam apalagi investigatif, sehingga dalam memaparkan sebuah peristiwa terdapat bias dalam pendefinisian, penjelasan, evaluasi, dan rekomendasi terkait masalah yang diberitakan.

Penelitian ini bermaksud menganalisis konstruksi kontra propaganda dalam pemberitaan media online dengan menggunakan analisis framing Robert N. Entman. Analisis framing digunakan untuk menelisik cara atau ideologi media ketika mengonstruksi fakta. Analisis ini mengamati strategi seleksi, penonjolan, dan pertautan fakta dalam berita sehingga sajian narasi lebih bermakna, menarik, berkesan, dan dapat menggiring interpretasi pembaca sesuai perpsketif media tersebut (Santosa, 2016). Peneliti memilih framing model Robert N. Entman karena dalam konsepsinya, framing Entman merujuk kepada pemberian definisi, penjelasan, evaluasi, dan rekomendasi dalam suatu naskah berita untuk memberi penekanan kerangka berpikir tertentu mengenai peristiwa yang diberitakan.

Media berita online yang menjadi perhatian peneliti adalah Tempo.co. Alasan pemilhan media berita online Tempo.co dikarenakan Tempo.co merupakan pionir portal berita online sejak 1995. Perbedaan media berita online Tempo.co dengan media berita lainnya adalah ketajaman dan keberimbangan dalam memberitakan berbagai fenomena sosial. Sebagai media berita online pemberitaan Tempo.co termasuk cepat dalam memberitakan sebuah informasi. Kemudian Tempo.co termasuk yang paling banyak memberitakan tentang Papua tidak hanya dari sektor politik, namun juga sektor ekonomi bisnis, travel atau pariwisata, video liputan dan gaya hidup (lifestyle). Semua pemberitaan tersebut dapat diperoleh dalam satu website, yaitu www.tempo.co. Terkait penelitian ini, Tempo.co dipilih untuk dianalisis karena kredibilitas pemberitaannya mengenai Papua. Oleh karena itu peneliti ingin melihat bagaimana Tempo. co merespon bentuk propaganda yang dikeluarkan oleh ULMWP dan Benny Wenda melalui Deklarasi Negara Papua Barat pada tanggal 1 Desember 2020 yang lalu.

Dahulu berbentuk majalah bernama Tempo yang merupakan salah satu varian dari Tempo Media Group yang cenderung membahas berita politik. Tempo menjadi majalah pertama yang tidak memiliki afiliasi dengan pemerintah. Pernah dibredel pada tahun 1982 dan 1994 karena 
terlalu tajam mengkritik rezim Orde Baru dan Golkar serta pemerintahan Soeharto. Mengikuti perkembangan zaman, kini Tempo dapat diakses dalam bentuk digital dengan nama situs Tempo. co. Sejak tahun 2008, Tempo.co telah reborn dengan wajah baru dengan tetap mempertahankan kualitas dalam penyajian berita, dengan upaya menerapkan standar tinggi jurnalisme dalam peliputan suatu peristiwa dan menuliskannya secara tajam, cerdas dan berimbang (Lingga \& Syam, 2018). Kepemilikan Tempo Media Group tidak dimiliki oleh individu seperti media massa lain, sehingga memungkinkan memiliki objektivitas dalam pemberitaan baik cetak maupun online. Dari penelusuran di situs resmi Tempo.co, terdapat moto dari media online ini yaitu "Tempo, Untuk Publik, Untuk Republik". Oleh karena itu menarik bagi peneliti untuk melihat bagaimana framing yang dilakukan oleh media online dalam merespon propaganda Deklarasi Negara Papua Barat (Tempo.co, 2021).

Studi terdahulu yang membahas mengenai Deklarasi Negara Papua Barat belum pernah dilakukan karena peristiwa tersebut terjadi pada tanggal 1 Desember 2020, sekitar satu bulan sebelum penelitian ini dibuat. Akan tetapi ada penelitian-penelitian lain yang berhubungan dengan fokus dalam tulisan ini terkait masalah Papua banyak ditemukan dan dipadukan dengan studi mengenai framing media dijadikan pijakan dalam penelitian ini. Pertama adalah jurnal karya Efa Rubiwati (2018), berjudul "Papua Dalam Media: Analisis Framing Pemberitaan Otonomi Khusus Di Papua Barat". Penelitian memaparkan konstruksi realitas yang dilakukan media, menggunakan analisis framing Robert N. Entman terhadap "Radar Sorong" dan "Antara Papua Barat". Didapatkan hasil bahwa "Radar Sorong" menekankan bahwa otonomi khusus di Papua Barat perlu dievaluasi sedangkan "Antara Papua Barat" cenderung mendukung penerapan otonomi khusus. Hal ini terjadi karena faktor kepentingan ekonomi dan politik, hegemoni media, dan rezim representasi, serta pengaruh strukturasi dalam institusi media (Rubiwati, 2018).

Selanjutnya penelitian Ulfa Kusmiarti (2020), berjudul "Framing Pemberitaan Kompas. com Dalam Kasus Diskriminasi dan Rasisme Mahasiswa Papua di Surabaya Periode 16 Agustus - 21 Agustus 2019”, menunjukkan bahwa Kompas.com mampu menjaga kredibilitas dalam memberitakan sebuah informasi dengan pemberitaan yang cenderung positif, penggunaan judul yang sesuai dengan isi, penulisan berita tidak menyudutkan salah satu pihak, dan pemilihan narasumber yang menjadi kunci kasus. Penelitian ini menjadi acuan bagaimana penggambaran suatu media terhadap kasus berhubungan dengan SARA (Kusmiarti, 2020).

Ketiga adalah penelitian mengenai isu propaganda karya Gian Noor Syah Putra, Tri Legionosuko, dan Adnan Madjid (2019) dengan judul "Strategi Pemerintah Indonesia Terhadap Negara-Negara Anggota Melanesian Spearhead Group (MSG) Dalam Menghadapi Propaganda Organisasi Papua Merdeka (OPM): Studi Kasus Negara Republik Vanuatu”. Hasil penelitian menjelaskan salah satu dari 3 langkah Pemerintah Indonesia melawan propaganda OPM adalah meng-counter isu-isu yang dipropagandakan OPM melalui dukungan teknologi dan informasi (Putra et al., 2019).

Berbeda dengan studi sebelumnya, di mana penelitian pertama mengkomparasi framing dari dua media berbeda, membahas masalah dari dalam negeri. Penelitian kedua melihat bagaimana media melakukan framing terkait kasus SARA dengan tetap menjaga kredibilitas. Serta penelitian ketiga yang melakukan kajian terhadap propaganda kasus rasisme di Papua dengan metodologi kualitatif deskriptif analitik. Pada penelitian ini membahas peristiwa yang baru saja terjadi yaitu Deklarasi Negara Papua Barat oleh Benny Wenda, pimpinan ULMWP yang berada di luar wilayah kedaulatan Indonesia, sehingga menambah aktualitas (kebaruan) tulisan ini. Perbedaan lain adalah tulisan ini berusaha untuk melihat framing yang dilakukan oleh media untuk meng-counter propaganda (kontra propaganda) melalui pemberitaan. 
Masalah yang dirumuskan penelitian ini adalah; (1) Bagaimana pembingkaian media online Tempo.co dalam teks berita tentang Deklarasi Negara Papua Barat? (2) Bagaimana kontra propaganda terkonstruksi dalam framing pemberitaan Tempo.co tentang Deklarasi Negara Papua Barat? Maka yang menjadi tujuan dari penelitian ini adalah untuk mengetahui bagaimana framing yang dilakukan dalam pemberitaan Tempo.co pada bulan Desember 2020, terkonstruksi sebagai kontra propaganda terhadap aksi Deklarasi Negara Papua Barat.

\section{METODE}

Jenis penelitian ini adalah penelitian kualitatif dengan paradigma konstruksivis. Penelitian kualitatif adalah penelitian yang menggunakan setting ilmiah, dengan tujuan memberi interpretasi pada fenomena yang terjadi dengan melibatkan berbagai metode lainnya (Moleong, 2014). Sedangkan paradigma konstruktivis untuk mengetahui bagaimana konstruksi yang dibangun oleh Tempo.co dalam pembingkaian kasus Deklarasi Negara Papua Barat dapat menciptakan sebuah realitas media. Media berita online Tempo.co merupakan Unit Amatan dalam penelitian ini dengan alamat situs resmi https://tempo.co. Sedangkan Unit Analisis penelitian adalah berita yang diterbitkan oleh Tempo.co selama periode Bulan Desember 2020.

Teknik analisis data mengacu pada teknik analisis Miles, Huberman, \& Saldana (2020), dengan langkah-langkah sebagai berikut: (1) peneliti mengumpulkan data primer dan sekunder. Data Primer diperoleh melalui penelusuran internet di situs Tempo.co, di mana peneliti menemukan 17 artikel yang memberitakan tentang Deklarasi Negara Papua Barat oleh Benny Wenda. Peneliti mengambil data sekunder melalui studi kepustakaan dengan membaca artikel, jurnal, buku, internet, dan sebagainya. Data yang diperoleh kemudian akan dikondensasi untuk mengelompokkan data dari pemberitaan Tempo.co; (2) peneliti menyajikan data dalam bentuk naratif dan tabel dalam menganalisis berita menggunakan analisis framing dari Robert $\mathrm{N}$. Entman untuk menggambarkan proses seleksi dan menonjolkan aspek tertentu dari realitas oleh media. Ada empat kategorisasi elemen dalam model analisis framing Robert N. Entman, yaitu yang pertama Define Problem, bagaimana suatu isu atau peristiwa dilihat? sebagai apa? Atau masalah apa? Kedua Diagnose Cause, apa penyebab peristiwa tersebut? apa yang dianggap penyebab masalah? Ketiga Moral Judgement, yang menilai moral seperti apa yang ditampilkan untuk menjelaskan masalah? atau nilai mental seperti apa yang digunakan untuk melegitimasi atau mendelegitimasi aksi/tindakan? keempat Treatment Recommendation, merujuk pada apa atau bagaimana format penyelesaian yang dipilih untuk mengatasi masalah? (Launa, 2020); (3) peneliti menarik kesimpulan dan memverifikasi data yang telah dianalisis dengan riset sejenis terkait analisis media dan kontra propaganda.

\section{HASIL DAN PEMBAHASAN}

Sepanjang bulan Desember 2020 hingga tulisan ini disusun, penulis menemukan setidaknya tujuh belas teks berita yang terkait dengan Deklarasi Negara Papua Barat pada media online Tempo.co. Dari ketujuh belas teks tersebut secara purposif diseleksi untuk dianalisis. Pemilihan empat teks berita tersebut adalah karena keempat teks berita tersebut dinilai cukup representatif dalam mewakili sampel untuk dianalisis. 
DOI: $10.24198 /$ jkj.v5i1.31885

Tabel 1. Teks Berita Tempo.co

\begin{tabular}{|c|c|c|c|}
\hline Tanggal Terbit & Rubrik & Waktu Terbit & Judul Berita \\
\hline Rabu, 2/12/2020 & Nasional & $15: 46$ & $\begin{array}{c}\text { "Benny Wenda Deklarasi Pemerintah Papua Barat, } \\
\text { Polri: Ini Bentuk Provokasi" }\end{array}$ \\
\hline Rabu, 2/12/2020 & Nasional & $14: 26$ & $\begin{array}{c}\text { "Tentara Pembebasan Papua Barat Tolak Deklarasi } \\
\text { Kemerdekaan Benny Wenda" }\end{array}$ \\
\hline Kamis, 3/12/2020 & Nasional & $14: 30$ & $\begin{array}{c}\text { "Mahfud Md: Benny Wenda Buat Negara Ilusi, } \\
\text { Rakyat Tidak Perlu Takut" }\end{array}$ \\
\hline Jum'at, 4/12/2020 & Nasional & $10: 23$ & $\begin{array}{r}\text { "Deklarasi Pemerintahan Papua Barat, Benny Wenda } \\
\text { Siap Duduk Bersama Jokowi" }\end{array}$ \\
\hline
\end{tabular}

Sumber: Tempo.com

Frame Berita 1. Judul berita "Benny Wenda Deklarasi Pemerintah Papua Barat, Polri: Ini Bentuk Provokasi" (edisi Rabu, 2 Desember 2020) dikonstruksi dengan jelas dalam dua kalimat. Kalimat pertama "Benny Wenda Deklarasi Pemerintah Papua Barat," yang merupakan kalimat berita kemudian kalimat kedua "Polri: Ini bentuk provokasi" yang merupakan kalimat penjelas dari kalimat pertama. Gabungan kedua kalimat tersebut menegaskan bahwa Deklarasi Pemerintah Papua Barat adalah hal yang provokatif dan negatif.

Tabel 2. Analisis Teks Berita 1

\begin{tabular}{|c|c|c|c|}
\hline Judul Berita & Elemen & Framing & Sumber Berita \\
\hline \multirow{4}{*}{$\begin{array}{l}\text { Benny Wenda } \\
\text { Deklarasi } \\
\text { Pemerintah Papua } \\
\text { Barat, Polri: Ini } \\
\text { Bentuk Provokasi }\end{array}$} & Define of Problems & $\begin{array}{l}\text { Deklarasi Pemerintah Papua Barat } \\
\text { oleh Benny Wenda adalah bentuk } \\
\text { provokasi dan propaganda. }\end{array}$ & \multirow{4}{*}{$\begin{array}{l}\text { BrigJen Awi Setiyono } \\
\text { (Kepala Biro Penerangan } \\
\text { Masyarakat Divisi Humas } \\
\text { Mabes Polri }\end{array}$} \\
\hline & Diagnose Causes & $\begin{array}{l}\text { Benny Wenda dan pengikutnya } \\
\text { mendeklarasikan diri membentuk } \\
\text { pemerintahan sementara dengan } \\
\text { Benny yang saat ini tengah berada } \\
\text { dalam pelarian di Inggris itu } \\
\text { sebagai presiden sementara. }\end{array}$ & \\
\hline & $\begin{array}{l}\text { Make Moral } \\
\text { Judgement }\end{array}$ & $\begin{array}{l}\text { "Karena sampai saat ini Papua dan } \\
\text { Papua Barat masih sah di bawah } \\
\text { NKRI dan hal ini sudah final, tidak } \\
\text { bisa ditawar-tawar lagi" }\end{array}$ & \\
\hline & $\begin{array}{l}\text { Treatment } \\
\text { Recomendation }\end{array}$ & $\begin{array}{l}\text { Awi pun mengingatkan masyarakat } \\
\text { Indonesia khususnya Papua agar } \\
\text { tidak terprovokasi dengan agenda } \\
\text { organisasi pimpinan Benny Wenda } \\
\text { itu. }\end{array}$ & \\
\hline
\end{tabular}

Sumber: Data olahan peneliti (2021)

Problem identification. Tempo.co mengonstruksi narasi secara langsung dengan mengutip pernyataan Brigjen Awi Setiyono, "Ini adalah salah satu bentuk provokasi, propaganda...," Kalimat ini menegaskan bahwa Deklarasi Negara Papua Barat merupakan provokasi dan propaganda dari Benny Wenda untuk memengaruhi masyarakat Papua dan Papua Barat khususnya berjuang melepaskan diri dari NKRI. Pemilihan diksi "provokasi" (p1, p2) yang memiliki kesan negatif dibandingkan dengan persuasif oleh Tempo.co digunakan untuk mengarahkan opini publik terkait Deklarasi Pemerintah Papua Barat oleh Benny Wenda merupakan sebuah hal yang negatif.

Causal interpretation. Menganalisa keseluruhan teks berita Tempo.co, ambisi Benny Wenda memerdekakan Papua Barat dari Indonesia dan mengangkat dirinya sebagai presiden sementara diposisikan sebagai penyebab masalah dalam narasi berita. Pada paragraf 5 Tempo.co menuliskan: "Sebelumnya, deklarasi kemerdekaan diserukan oleh ULMWP 
yang diprakarsai oleh Tokoh Pembebasan Papua Barat, Benny Wenda. Ia pun mengklaim dirinya sebagai presiden." Dan pada paragraf 6 dituliskan: "Benny Wenda dan pengikutnya mendeklarasikan diri membentuk pemerintahan sementara dengan Benny yang saat ini tengah berada dalam pelarian di Inggris itu sebagai presiden sementara." Pemilihan frase "mengklaim dirinya," dan "mendeklarasikan diri," menunjukkan aksi sepihak yang dilakukan oleh Benny Wenda. Penguatan bahwa aksi tersebut adalah negatif ditunjukkan dengan kata "pelarian" yang memiliki konotasi negatif. Labelling "pelarian" terhadap Benny Wenda menguatkan konstruksi berita Tempo.co terhadap Benny Wenda sebagai penyebab masalah.

Moral Evaluation. Evaluasi moral dapat kita lihat dalam naskah berita pada paragraf 4. Tempo.co menulis: "sampai saat ini Papua dan Papua Barat masih sah di bawah NKRI dan hal ini sudah final, tidak bisa ditawar-tawar lagi," Kalimat ini merupakan sebuah pernyataan tegas bahwa jika ada yang berniat memecah belah NKRI maka hal tersebut merupakan tindakan makar dan tidak bermoral. Klaim moral dalam konstruksi berita ini dapat menjatuhkan citra Benny Wenda dan segala agenda organisasinya terkait Deklarasi Negara Papua Barat.

Treatment recommendation. Dari analisis secara keseluruhan narasi, Tempo.co memberi rekomendasi: (1) "Deklarasi Pemerintahan Sementara Merdeka dari Indonesia pada 1 Desember 2020, merupakan salah satu bentuk provokasi” (p1); (2) "sampai hari, kemarin pun 1 Desember keamanan dan ketertiban kondusif," (p2); (3) "Awi pun kembali mengingatkan masyarakat Indonesia khususnya Papua agar tidak terprovokasi dengan agenda organisasi pimpinan Benny Wenda itu." (p3); (4) "Deklarasi itu disebut-sebut dilakukan pada 1 Desember kemarin namun tak ada kejelasan waktu dan tempat pelaksanaan deklarasi." (6). Rekomendasi dari Tempo. co ini membingkai Benny Wenda dan Deklarasi Pemerintah Papua Barat adalah propaganda negatif sehingga masyarakat tidak perlu terprovokasi hal tersebut.

Frame Berita 2. Judul berita "Tentara Pembebasan Papua Barat Tolak Deklarasi Kemerdekaan Benny Wenda" (edisi Rabu, 2 Desember 2020) disajikan Tempo.co dengan menyertakan narasumber dari TPNPB-OPM yang merupakan pejuang kemerdekaan Papua yang beroperasi di dalam wilayah Papua, Indonesia. Wacana penolakan dari Tempo.co disembunyikan dengan mengedepankan wacana penolakan dari dalam masyarakat Papua sendiri. Narasi yang dibuat Tempo.co seolah menyatakan tidak adanya dukungan pada Deklarasi sepihak Benny Wenda, bahkan dari dalam masyarakat Papua itu sendiri.

Tabel 3. Analisis Teks Berita 2

\begin{tabular}{|c|c|c|c|}
\hline Judul Berita & Elemen & Framing & Sumber Berita \\
\hline \multirow{4}{*}{$\begin{array}{l}\text { Tentara } \\
\text { Pembebasan } \\
\text { Papua Barat } \\
\text { Tolak Deklarasi } \\
\text { Kemerdekaan } \\
\text { Benny Wenda }\end{array}$} & Define of Problems & $\begin{array}{l}\text { Penolakan TPNPB-OPM atas } \\
\text { klaim Benny Wenda yang } \\
\text { dideklarasikan di negeri asing }\end{array}$ & \multirow{4}{*}{$\begin{array}{l}\text { Sebby Sembom } \\
\text { (Juru Bicara Tentara } \\
\text { Pembebasan Nasional } \\
\text { Papua Barat - Organisasi } \\
\text { Papua Merdeka) }\end{array}$} \\
\hline & Diagnose Causes & $\begin{array}{l}\text { Status kewarganegaraan asing } \\
\text { Benny Wenda dan deklarasi } \\
\text { dilakukan di luar wilayah hukum } \\
\text { revolusi }\end{array}$ & \\
\hline & $\begin{array}{l}\text { Make Moral } \\
\text { Judgement }\end{array}$ & $\begin{array}{l}\text { Benny Wenda merusak persatuan } \\
\text { dalam Perjuangan bangsa Papua } \\
\text { dan dianggap bekerja untuk } \\
\text { kepentingan kapitalis asing Uni } \\
\text { Eropa, Amerika, dan Australia. }\end{array}$ & \\
\hline & $\begin{array}{l}\text { Treatment } \\
\text { Recomendation }\end{array}$ & $\begin{array}{l}\text { Manajemen Markas Pusat } \\
\text { KOMNAS TPNPB-OPM } \\
\text { mengumumkan mosi tidak percaya } \\
\text { kepada Benny Wenda }\end{array}$ & \\
\hline
\end{tabular}

Sumber: Data olahan peneliti (2021) 
Problem identification. Dalam teks berita ini wacana penolakan ditempatkan oleh Tempo. co dalam mengaitkan pernyataan Benny Wenda, pemimpin ULMWP, terkait pembentukan Pemerintahan Sementara West Papua pada Selasa, 1 Desember. Penolakan tersebut secara jelas ditekankan dengan narasi "Tentara Pembebasan Nasional Papua Barat-Organisasi Papua Merdeka (TPNPB-OPM) menolak pernyataan dari The United Liberation Movement for West Papua (ULMWP) (p1). Kemudian menonjolkan pernyataan tertulis dari narasumber berita dalam kalimat: "TPNPB-OPM sangat tidak mengakui dan tidak akan kompromi dengan Benny Wenda, karena Benny Wenda deklarasi Negara Papua Barat dan berkantor di Inggris yang bukan merupakan daerah revolusi," (p6). Peneliti mengidentifikasi pada paragraf 1 bahwa arah framing tertuju pada apa yang dilakukan oleh ULMWP dan pemimpinnya Benny Wenda ditentang oleh TPNPB-OPM yang beroperasi di wilayah Papua dan Papua Barat dan masih berada di wilayah kedaulatan Indonesia. Sedangkan pada paragraf 6 berita dikonstruksi seolaholah pernyataan Benny Wenda atas Deklarasi negara Papua Barat tersebut merupakan klaim sepihak dan tidak diakui oleh TPNPB-OPM yang merepresentasi seluruh rakyat Papua.

Causal interpretation. Substansi makna dari narasi berita penolakan TPNPB-OPM atas Deklarasi Negara Papua Barat oleh Benny Wenda tersebut dikonstruksi pada kegagalan ULMWP dan Benny Wenda dalam perjuangan bangsa Papua. Terlihat dari teks pada paragraf 2 dengan mengutip keterangan tertulis Sebby Sembom: "Benny Wenda adalah Warga Negara Inggris dan menurut hukum internasional bahwa warga Negara Asing tidak bisa menjadi President Republic Papua Barat," kemudian pada paragraf 4: "Sebby mengatakan klaim Benny tersebut menunjukkan kegagalan ULMWP dan Benny Wenda. TPNPB, kata Sebby, tidak mengakui klaim Benny karena dideklarasikan di negeri asing.

Moral Evaluation. Klaim moral dikonstruksi Tempo.co pada status kewarganegaraan Benny Wenda serta deklarasi yang dilakukan di negeri asing (Inggris) itu sebagai penyebab masalah, tidak mempunyai legitimasi mayoritas Rakyat Bangsa Papua. Sebaliknya juru bicara TPNPB-OPM, Sebby Sembom yang mewakili sebagian besar rakyat Papua dan berjuang dari wilayah revolusi terkonstruksi sebagai korban ambisi sepihak Benny Wenda. Penekanan pada evaluasi moral ini diperkuat dengan tulisan “....jelas-jelas Benny Wenda merusak persatuan dalam Perjuangan bangsa Papua... Benny Wenda (diketahui) kerja (untuk) kepentingan kapitalis asing Uni Eropa, Amerika, dan Australia,... hal ini bertentangan dengan prinsip-prinsip revolusi untuk kemerdekaan bagi bangsa papua" (p8).

Treatment recommendation. Rekomendasi Tempo.co dalam narasi berita ini adalah (1) "...deklarasi (Benny Wenda) itu tidak mempunyai legitimasi mayoritas Rakyat Bangsa Papua," (p7); (2) "Manajemen Markas Pusat KOMNAS TPNPB-OPM mengumumkan mosi tidak percaya kepada Benny Wenda," (p7). Rekomendasi Tempo.co yang mengutip keterangan juru bicara TPNPB-OPM yang menyatakan mosi tidak percaya kepada Benny Wenda teridentifikasi untuk membentuk opini publik bahwa tidak ada pengakuan baik dari negara Indonesia maupun dari mayoritas rakyat Papua sendiri terhadap Deklarasi Negara Papua Barat.

Frame Berita 3. Judul berita "Mahfud Md: Benny Wenda Buat Negara Ilusi, Rakyat Tidak Perlu Takut" (edisi Kamis, 3 Desember 2020). Tempo.co menyajikan framing dari berita mengenai Deklarasi Negara Papua Barat oleh Benny Wenda dengan mengedepankan sudut pandang hukum dalam narasi berita ini, dengan melibatkan narasumber Menteri Koordinator Bidang Politik, Hukum, dan Keamanan Mahfud Md dengan mengutip penyataan MenkoPolHuKam dalam konferensi pers virtual. Penulisan frase "Negara Ilusi" pada judul berita menunjukkan framing terhadap Deklarasi Negara Papua Barat sebagai negara yang tidak nyata (fiktif), atau dengan kata lain Deklarasi Negara Papua Barat adalah sebuah pembohongan publik. Pada kalimat "Rakyat Tidak Perlu Takut" Tempo,co ingin menunjukkan seolah seluruh 
bangsa Indonesia dan masyarakat Papua khususnya tidak mau NKRI terpecah-belah oleh klaim pemimpin ULMWP Benny Wenda tersebut.

Tabel 4. Analisis Teks Berita 3

\begin{tabular}{|c|c|c|c|}
\hline Judul Berita & Elemen & Framing & Sumber Berita \\
\hline \multirow{4}{*}{$\begin{array}{l}\text { Mahfud Md: } \\
\text { Benny Wenda } \\
\text { Buat Negara Ilusi, } \\
\text { Rakyat Tidak Perlu } \\
\text { Takut }\end{array}$} & Define of Problems & $\begin{array}{l}\text { Benny Wenda sedang } \\
\text { membuat negara ilusi dengan } \\
\text { mendeklarasikan pembentukan } \\
\text { Pemerintah Sementara Papua } \\
\text { Barat }\end{array}$ & \multirow{4}{*}{$\begin{array}{l}\text { Mahfud Md. } \\
\text { (Menteri Koordinator } \\
\text { Bidang Politik, Hukum, } \\
\text { dan Keamanan) }\end{array}$} \\
\hline & Diagnose Causes & $\begin{array}{l}\text { Negara yang dibuat Benny Wenda } \\
\text { tidak memenuhi unsur-unsur } \\
\text { berdirinya sebuah negara menurut } \\
\text { Konvensi Montevideo }\end{array}$ & \\
\hline & $\begin{array}{l}\text { Make Moral } \\
\text { Judgement }\end{array}$ & $\begin{array}{l}\text { Tidak mungkin seorang pemimpin } \\
\text { negara berstatus Narapidana dan } \\
\text { tidak memiliki kewarganegaraan }\end{array}$ & \\
\hline & $\begin{array}{l}\text { Treatment } \\
\text { Recomendation }\end{array}$ & $\begin{array}{l}\text { Rakyat tidak perlu takut karena } \\
\text { pemerintah dan aparat hukum } \\
\text { tetap akan menindak tegas Benny } \\
\text { Wenda dengan menggunakan pasal } \\
\text { kejahatan keamanan negara }\end{array}$ & \\
\hline
\end{tabular}

Sumber: Data olahan peneliti (2021)

Problem identification. Deklarasi Negara Papua Barat oleh Benny Wenda kembali ditempatkan sebagai masalah utama oleh Tempo.co. Aspek hukum serta syarat berdirinya sebuah negara lebih ditekankan dalam naskah berita ini. Konstruksi opini sebagai negara ilusi terdapat dalam kalimat "Benny Wenda sedang membuat negara ilusi dengan mendeklarasikan pembentukan Pemerintah Sementara Papua Barat." (p1). "Benny Wenda ini membuat negara ilusi. Negara yang tidak ada dalam faktanya," (p2). Kemudian kalimat "Itu (Deklarasi Negara Papua Barat) kan ilusi saja." (p5). Dengan penggunaan kata "ilusi" menunjukkan sifat dari judul berita Tempo.co ini insinuatif (sindiran tidak langsung) dan tendensius.

Causal interpretation. Penekanan Tempo.co dari sisi hukum dan syarat berdirinya sebuah negara menjadi substansi narasi berita dengan menonjolkan pernyataan dari narasumber dalam kalimat: “....ada empat unsur berdirinya negara menurut Konvensi Montevideo yakni, memiliki rakyat, wilayah, pemerintah dan pengakuan dari negara lain. Negara yang dibuat Benny Wenda... tidak memenuhi seluruh unsur itu.” (p3). Lalu diperkuat dengan kalimat “... sejak 1969 Komite 24 Perserikatan Bangsa-bangsa (PBB) tidak memasukkan Papua dalam daftar negara-negara yang dianggap memiliki peluang dan mandiri untuk merdeka.” (p4). Identifikasi yang didapat dari kalimat pada paragraf 3 dan 4 tersebut mengarahkan framing bahwa Deklarasi Negara Papua Barat oleh Benny Wenda tidak sah dan tidak mendapat pengakuan dari negaranegara lain.

Moral Evaluation. Klaim moral ditunjukkan kalimat "Benny Wenda itu seorang narapidana yang sekarang tidak punya kewarganegaraan (di tanah Papua - Indonesia red.). Lalu bagaimana dia memimpin negaranya?" (p5). Penggunaan kata "narapidana" dan "tidak punya kewarganegaraan" dalam kalimat tersebut mengidentifikasi framing terhadap Benny Wenda tidak pantas atau bahkan tidak bisa memimpin sebuah negara, karena syarat menjadi seorang presiden di antaranya harus memiliki kewarganegaraan serta tidak pernah dijatuhi pidana penjara berdasarkan putusan pengadilan yang berkekuatan hukum tetap (Presiden Republik Indonesia, 2008). Diperkuat dengan kalimat "Apalagi deklarasi kemerdekaan melalui Twitter," (p5) yang menguatkan konstruksi tidak adanya etika bernegara dari seorang Benny Wenda. Klaim moral dalam konstruksi berita seperti ini menunjukkan Tempo.co berusaha membuka 
ingatan publik terhadap fakta bahwa Benny Wenda pernah ditangkap dan dipenjara pada tahun 2012 oleh aparat hukum Indonesia di Papua namun berhasil melarikan diri dan menetap di Inggris sejak 2013. Pada paragraf 6 Tempo.co menyebutkan pernyataan Mahfud Md. “... tindakan Benny Wenda sudah masuk kategori kejahatan makar skala kecil.” (p6). Penggunaan kata "makar" yang memiliki arti pemberontakan melawan pihak yang berkuasa atau berwenang mengonstruksi posisi Benny Wenda sebagai pelanggar hukum.

Treatment recommendation. Analisis framing dari keseluruhan berita, Tempo.co merekomendasikan (1) "Rakyat tidak perlu terlalu takut.” (p5); (2) “...aparat hukum tetap akan menindak tegas Benny dan kelompok-kelompok yang berusaha memisahkan Papua dari Negara Kesatuan Republik Indonesia (NKRI)." (p6); (3) "Pemerintah menanggapi itu dengan cara Polri melakukan penegakan hukum." (p7). Kalimat-kalimat tersebut menunjukkan konstruksi berita terkait motif yang tersembunyi dari Tempo.co: bahwa negara tidak akan tinggal diam dalam kasus Deklarasi Negara Papua Barat, namun juga tidak mengganggap kasus tersebut sebuah ancaman besar yang mengganggu keutuhan NKRI.

Frame Berita 4. Judul berita "Deklarasi Pemerintahan Papua Barat, Benny Wenda Siap Duduk Bersama Jokowi” (edisi Jum'at, 4 Desember 2020). Judul terdiri dari dua kalimat. Pertama "Deklarasi Pemerintahan Papua Barat" sebagai kalimat utama yang menjadi persoalan, serta kalimat kedua "Benny Wenda Siap Duduk Bersama Jokowi" yang merupakan pernyataan kesiapan dari Benny Wenda bertemu dengan Jokowi untuk membahas masalah Kemerdekaan Papua. Secara keseluruhan dapat diidentifikasi Tempo.co mengonstruksi berita (1) Dengan Deklarasi Pemerintahan Papua Barat serta mendeklarasikan dirinya sebagai Presiden Sementara Papua Barat, Benny Wenda ingin melepaskan label separatis yang melekat padanya, dan menyejajarkan diri sebagai sesama pemimpin dengan Presiden Jokowi. (2) Penggunaan kata "Duduk Bersama" merujuk pada sebuah perundingan sesama pemimpin, menyamakan kedudukan dirinya dengan Presiden Jokowi yang ditunjukan dalam kalimat "Saya siap untuk duduk bersama Presiden, negara ke negara," (p2). (3) Dengan menyertakan Benny Wenda yang menjadi aktor penyebab masalah pemberitaan ini, mengindikasikan sebuah konstruksi pesan bahwa Tempo.co sebagai media massa yang kredibel dan terpercaya, dengan masih berpegang pada prinsip keberimbangan.

Tabel 5. Analisis Teks Berita 4

\begin{tabular}{|c|c|c|c|}
\hline Judul Berita & Elemen & Framing & Sumber Berita \\
\hline \multirow{4}{*}{$\begin{array}{l}\text { Deklarasi } \\
\text { Pemerintahan } \\
\text { Papua Barat, } \\
\text { Benny Wenda Siap } \\
\text { Duduk Bersama } \\
\text { Jokowi }\end{array}$} & Define of Problems & $\begin{array}{l}\text { Keinginan Benny Wenda untuk } \\
\text { bertemu dan menyatakan siap } \\
\text { untuk berunding dengan Presiden } \\
\text { Jokowi. }\end{array}$ & \multirow{4}{*}{$\begin{array}{l}\text { Benny Wenda } \\
\text { (Pimpinan ULMWP) } \\
\text { Mahfud Md. } \\
\text { (Menteri Koordinator } \\
\text { Bidang Politik, Hukum, } \\
\text { dan Keamanan) }\end{array}$} \\
\hline & Diagnose Causes & $\begin{array}{l}\text { Deklarasi Pemerintahan Papua } \\
\text { Barat dan Deklarasi Benny Wenda } \\
\text { sebagai Presiden Sementara Papua } \\
\text { Barat }\end{array}$ & \\
\hline & $\begin{array}{l}\text { Make Moral } \\
\text { Judgement }\end{array}$ & $\begin{array}{l}\text { Indonesia mengkategorikan } \\
\text { Deklarasi Pembentukan } \\
\text { Pemerintahan Sementara Papua } \\
\text { Barat oleh Benny Wenda dalam } \\
\text { kejahatan makar skala kecil }\end{array}$ & \\
\hline & $\begin{array}{l}\text { Treatment } \\
\text { Recomendation }\end{array}$ & $\begin{array}{l}\text { Pemerintah menanggapi dengan } \\
\text { cara Polri melakukan penegakan } \\
\text { hukum menggunakan pasal } \\
\text { kejahatam keamanan negara }\end{array}$ & \\
\hline
\end{tabular}

Sumber: Data olahan peneliti (2021) 
Problem identification. Pada paragraf pembuka Tempo.co langsung tertulis kalimat "Ketua The United Liberation Movement for West Papua (ULMWP) Benny Wenda, menyatakan kesiapannya untuk duduk dan membahas urusan Papua - Papua Barat dengan Presiden Joko Widodo." (p1). Menyebutkan nama Benny Wenda beserta organisasinya pada kalimat awal seolah menunjukkan bahwa berita ini merupakan ruang bagi Benny Wenda menyatakan pendapat sebagai penerapan asas keberimbangan suatu media berita. Pemilihan kata "... kesiapannya..." dalam kalimat menunjukkan bahwa Benny Wenda yang sebelumnya merasa belum siap, namun saat ini sudah siap bertemu Presiden karena merasa berada pada level yang sama dengan Presiden Jokowi. Di mana terdapat kalimat "Benny sebelumnya mendeklarasikan diri sebagai Presiden Sementara Papua Barat." Pemilihan kata "duduk" menunjukkan keberanian Benny Wenda untuk berunding masalah Papua - Papua Barat dengan Presiden Jokowi. Berita dikonstruksi seperti mengarah pada jalan damai penyelesaian konflik, namun Tempo.co secara implisit menyampaikan pesan bahwa dengan menganggap statusnya sebagai Presiden Sementara Papua Barat yang tidak mungkin akan dilepas, maka dapat diprediksi pertemuan yang dituju oleh Benny Wenda memiliki tujuan yang sama yaitu memerdekakan diri dari NKRI. Framing Tempo.co sebenarnya tidak berubah dengan menempatkan Benny Wenda sebagai aktor pembuat masalah (trouble maker).

Causal interpretation. Dalam narasi berita ini Tempo.co tetap menempatkan Deklarasi Pemerintahan Papua Barat dan Presiden Sementara Papua Barat adalah narasi yang menjadi latar belakang Benny Wenda menyatakan siap duduk bersama Jokowi. Konstruksi berita Tempo.co ini dilatarbelakangi interpretasi dari sebab akibat, yang dikuatkan dengan kalimat "ULMWP... menyatakan pembentukan pemerintah sementara yang bertujuan memobilisasi rakyat West Papua yang mencakup Provinsi Papua dan Papua Barat..., untuk mewujudkan referandum menuju kemerdekaan," (p5). Tempo.co mengonstruksi narasi untuk menyisipkan pesan tersembunyi bahwa permintaan Benny Wenda untuk duduk bersama Jokowi adalah hal yang sia-sia, karena tujuannya adalah mewujudkan referandum menuju kemerdekaan Papua.

Moral Evaluation. Framing yang menjadi klaim moral Tempo.co dapat dilihat pada narasi berita dengan penonjolan kalimat "Presiden harus mengakhiri masa darurat militer di Papua Barat dan duduk untuk membicarakan hal ini," (p4). Pemilihan diksi "harus" menjadikan kalimat tersebut adalah kalimat perintah, yang kemudian mengonstruksi bahwa Benny Wenda mewajibkan Presiden Jokowi mengakhiri masa darurat militer. Fakta bahwa Benny Wenda tidak dalam posisi memberi perintah kepada Presiden Jokowi, apalagi ia tidak berkewarganegaraan Indonesia kemudian membenarkan pernyataan Menkopolhukam Mahfud Md. Pada paragraf 6 “....Benny Wenda sudah masuk kategori kejahatan makar.” Dari keseluruhan substansi narasi dapat terindikasi framing berita Tempo.co ini ditujukan untuk mengonstruksi opini atas citra negatif Benny Wenda dan ULMWP. Dengan tetap mendelegitimasi Benny Wenda sebagai tokoh separatis, bukan Presiden Sementara Papua Barat.

Treatment recommendation. Dari framing berita Tempo.co yang dapat dikonstruksi, rekomendasi dalam naskah berita ini adalah (1) Negara menolak pernyataan Benny Wenda mengenai kesiapannya untuk duduk bersama Jokowi membahas permasalahan Papua - Papua Barat. Rekomendasi ini ditulis jelas pada naskah berita dengan kalimat "Pernyataan Benny ini mendapat penolakan dari Indonesia." (p6); (2) Pemerintah akan tetap menanggapi Benny Wenda dengan cara Polri melakukan penegakan hukum, karena Benny Wenda dianggap telah mengajak (memprovokasi) melakukan makar. Dua rekomendasi tersebut merujuk pada pembingkaian bahwa Tempo.co tidak akan memberikan panggung yang cukup luas bagi Benny Wenda dan Deklarasi Pemerintahan Papua Barat untuk dijadikan propaganda melawan kedaulatan NKRI. 
Dari keseluruhan hasil analisis framing Entman terhadap empat teks berita di atas, peneliti menyimpulkan framing Tempo.co terhadap Deklatrasi Negara Papua Barat adalah dengan mengonstruksi aksi tersebut sebagai propaganda untuk makar, dan Pemerintahan Sementara Papua Barat di Inggris adalah fiktif (hanya merupakan ilusi Benny Wenda). Dengan konstruksi tersebut Tempo.co menyiratkan pesan pada khalayak bahwa ideologi media Tempo.co adalah tidak mendukung kemerdekaan Papua Barat untuk lepas dari Indonesia.

\section{Kontra Propaganda dalam Konstruksi Media Tempo.co}

Aksi Deklarasi Negara Papua Barat diklaim sebagai bentuk kesuksesan perjuangan Benny Wenda dan ULMWP. Seperti pernyataan Benny Wenda yang dikutip dari SBS News pada 1 Desember 2020: "Ini hari sangat penting bagi rakyat saya. Kami sekarang memulihkan kedaulatan kami dan pemerintahan sementara kami di Papua Barat,". Pernyataan tersebut menunjukkan bahwa aksi Deklarasi Negara Papua Barat terindikasi propaganda dengan menggunakan teknik Bandwagon Effect.

Pada hasil analisis berita 1, dengan judul "Benny Wenda Deklarasi Pemerintah Papua Barat, Polri: Ini Bentuk Provokasi”, treatment recommendation dari Tempo.co yaitu membingkai Benny Wenda dan Deklarasi Pemerintah Papua Barat adalah bentuk propaganda negatif sehingga masyarakat tidak perlu terprovokasi hal tersebut. Himbauan agar masyarakat tidak terprovokasi terutama bagi masyarakat Papua atas Deklarasi Pemerintah Papua Barat dan pengangkatan Benny Wenda sebagai Presiden Sementara Papua Barat merupakan bentuk kontra propaganda terhadap agitasi Benny Wenda.

Kemudian pada berita 2, Rekomendasi Tempo.co yang mengutip keterangan juru bicara TPNPB-OPM yang menyatakan mosi tidak percaya kepada Benny Wenda teridentifikasi untuk membentuk opini publik bahwa tidak ada pengakuan baik dari negara Indonesia maupun dari mayoritas rakyat Papua sendiri terhadap Deklarasi Negara Papua Barat. Dalam hasil penelitian "Strategi Pemerintah Indonesia Terhadap Negara-Negara Anggota Melanesian Spearhead Group (MSG) Dalam Menghadapi Propaganda Organisasi Papua Merdeka (OPM): Studi Kasus Negara Republik Vanuatu", Putra et al., (2019) disebutkan bahwa Pemerintah Indonesia dinilai kurang mampu menahan propaganda OPM ke dunia internasional dikarenakan selalu menggunakan state actor. Sedangkan non-state actor yang dapat menjadi penyeimbang atas propaganda tidak pernah disertakan. Berita 2 paling menjadi perhatian karena respon langsung dari organisasi yang seharusnya satu tujuan dengan ULMWP dan Benny Wenda. Mengangkat juru bicara TPNPB-OPM sebagai narasumber dalam pemberitaan adalah konstruksi teks media dengan menyertakan non-state actor untuk menyangkal propaganda Benny Wenda yang mendeklarasikan Negara Papua Barat dengan mengatasnamakan seluruh rakyat Papua. Hal ini sekaligus meredam teknik propaganda Bandwagon Effect pada Deklarasi Negara Papua Barat tersebut.

Berita 3 menunjukkan konstruksi berita terkait motif yang tersembunyi dari Tempo.co: bahwa negara tidak akan tinggal diam dalam kasus Deklarasi Negara Papua Barat, namun juga tidak mengganggap kasus tersebut sebuah ancaman besar yang mengganggu keutuhan NKRI. Konstruksi pada berita 3 memberi peringatan kepada propagandis, bahwa keberadaan wilayah Papua sebagai bagian dari Indonesia dilindungi oleh hukum internasional dan konstitusi. Sehingga bagi siapa saja yang berlawanan dengan hal tersebut akan dikategorikan sebagai makar dan ditindak tegas. Hal ini menunjukkan kontra propaganda terhadap yang ditujukan secara langsung pada aktor Deklarasi Negara Papua Merdeka, dan tidak langsung kepada pihak asing yang mendukung kemerdekaan Papua Barat.

Lalu pada teks berita 4 dinyatakan Negara menolak pernyataan Benny Wenda mengenai 
kesiapannya untuk duduk bersama Jokowi membahas permasalahan Papua - Papua Barat. Ini adalah sebuah kontra propaganda dalam teks media untuk tidak mengakui Benny Wenda sebagai Presiden Sementara Negara Republik Papua Barat, dan tidak mengakui Pemerintahan Sementara Papua Barat.

Dari hasil interpretasi peneliti mengenai kontra propaganda tersebut dapat dipahami bahwa dalam kontra terhadap propaganda dalam teks media ada yang telihat atau terbaca dengan penggunaan kata-kata yang jelas maksudnya seperti 'makar' pada berita 3. Namun juga ada yang tersirat seperti contoh pada berita 2 dan 4. Konstruksi teks media Tempo.co dalam keempat berita tersebut merupakan kontra propaganda dengan menegaskan status papua sebagai bagian dari Indonesia sebagai satu-satunya entitas yang memiliki kendali atas papua dilindungi oleh hukum internasional, sehingga tidak ada pengakuan dari pihak manapun atas Deklarasi Negara Papua Barat tersebut.

Ditinjau dari perspektif ilmu komunikasi, propaganda pada dasarnya adalah bentuk komunikasi yang memiliki tujuan akhir agar pesan yang disampaikan propagandis dapat diterima oleh target khalayak, sehingga diperlukan strategi dalam proses komunikasi tersebut (Sadarusalam \& Hasan, 2019). Hal tersebut berlaku sama dengan pemberitaan media massa yang berusaha memberi pemahaman terhadap khalayak. Isi dari media massa tidak terlepas dari ideologi berupa citra ideal yang dikemas seperti fakta dan dipahami sebagai realitas konkret. Ideologi media massa inilah yang kemudian menentukan visi atau pandangan media terhadap suatu realitas (Santosa, 2016). Oleh karena itu, kontra propaganda juga merupakan strategi komunikasi media massa terhadap khalayak melawan propaganda itu sendiri. Berdasarkan hal tersebut, peneliti melihat konstruksi pemberitaan Tempo.co terkait Deklarasi Negara Papua Barat merupakan strategi kontra propaganda dalam teks media.

\section{SIMPULAN}

Pembingkaian media online Tempo.co terhadap Deklarasi Negara Papua Barat adalah framing negatif, dengan mengonstruksi realitas pada pemberitaan bahwa Deklarasi Negara Papua Barat adalah salah satu bentuk propaganda dan tergolong pada tindakan makar, yang dipimpin oleh seorang pelarian (narapidana) yang telah dicoret kewarganegaraannya sebagai WNI. Tidak ada pihak manapun yang mengakui Deklarasi Negara Papua Barat karena menyalahi hukum internasional serta tidak memenuhi syarat-syarat pembentukan suatu negara. Kontra Propaganda terkonstruk dari framing teks media yang menegaskan status Papua sebagai bagian dari Indonesia sebagai satu-satunya entitas yang memiliki kendali atas Papua dilindungi oleh hukum internasional, sehingga tidak akan ada pengakuan dari pihak manapun atas Deklarasi Negara Papua Barat tersebut. Peneliti menemukan bahwa Kontra Propaganda pada Konstruksi Media Tempo.co dalam penelitian ini, pada saat yang bersamaan juga menjadi bentuk Propaganda dari media itu sendiri dalam menyatakan keberpihakan atau sikap politiknya (Political Stance). Dalam kasus propaganda isu Deklarasi Negara Papua Barat, kontra propaganda yang dikonstruksi oleh Tempo.co dalam teks beritanya merupakan Propaganda dari citra Tempo.co sebagai media pro-NKRI. Seperti moto Tempo Media Group yaitu: "Tempo, Untuk Publik, Untuk Republik."

Dari hasil analisis dan kesimpulan, peneliti memberikan rekomendasi bagi media massa Tempo.co dalam menulis berita yang kontra terhadap propaganda Deklarasi Negara Papua Barat, agar tidak berorientasi pada propaganda tersebut, sehingga fokus tulisan hanya pada arena konflik. Karena hal tersebut bertentangan dengan prinsip jurnalisme damai dan dapat beresiko mempertajam konflik. Sebuah propaganda dalam sebuah konflik kerap berfokus pada hal-hal yang menguntungkan bagi propagandis, dalam kasus ini contohnya adalah isu 
HAM yang diinternasionalisasi bagi keuntungan ULMWP dan Benny Wenda. Mengonstruksi pemberitaan kontra propaganda dengan mengambil perspektif lain di luar arena propaganda politik seperti pembangunan, pendidikan, gaya hidup, ekonomi, hiburan, pariwisata, dan sebagainya, akan memberi informasi dan pemahaman yang lebih baik bagi pembaca agar tidak mudah terpengaruh oleh propaganda yang dapat mengganggu keutuhan NKRI. Adanya isu internasionalisasi konflik Papua Barat oleh ULMWP, perlu kita mengetahui konstruksi media asing dalam pemberitaan mengenai kasus Papua. Penelitian tersebut dapat menjadi screening tergadap isu mengenai kepentingan asing terhadap kasus Papua, sebagai langkah preventif melawan propaganda dengan mempersiapkan literasi yang baik tidak hanya sekadar penyangkalan semata. Penelitian lebih lanjut perlu dilakukan oleh para akademisi dan penggiat media yang peduli terhadap keutuhan Negara Kesatuan Republik Indonesia, dengan menyertakan data-data empiris dari lapangan untuk menggali lebih jauh terkait ideologi media dan strategi media melawan propaganda. Dengan menganalisis pandangan khalayak yang menjadi tujuan propaganda melalui analisis resepsi, agar dapat diketahui sejauh mana masyarakat terpapar oleh propaganda dan menentukan langkah-langkah komunikasi strategis untuk melawan propaganda tersebut melalui konstruksi pemberitaan.

\section{DAFTAR PUSTAKA}

Aditya, P., \& Sukendro, G. G. (2020). Propaganda analysis in the movie Che: The Argentine. Proceedings of the 2nd Tarumanegara International Conference on the Applications of Social Sciences and Humanities (TICASH 2020), 478, 965-968. https://doi.org/10.2991/ assehr.k.201209.152

Alam, S. (2020). Jurnalisme damai dalam pembingkaian berita rasisme mahasiswa Papua di Tribunnews.com dan Detik.com. Jurnal Pewarta Indonesia, 2(2), 121-136. https://doi. org/10.25008/jpi.v2i2.33

Alfiyani, N. (2018). Media sosial sebagai strategi komunikasi politik. Potret Pemikiran, 22(1), 57-69. https://doi.org/10.30984/pp.v22i1.762

Fahmi, I. (2019). Tiadanya kontra narasi internasional tentang "West Papua.” Diakses January 14, 2021, dari Drone Emprit: Software for media monitoring and analytics website: https://pers.droneemprit.id/tiadanya-kontra-narasi-internasional-tentang-west-papua/

Ilmar, A. (2017). Radikalisme gerakan berbasis etnis: Kasus Organisasi Papua Merdeka. IJPA-The Indonesian Journal of Public Administration, 3(2), 72-87. Diakses dari http:// journal.uta45jakarta.ac.id/index.php/admpublik/article/view/990

Kusmiarti, U. (2020). Framing pemberitaan Kompas.com dalam kasus diskriminasi dan rasisme mahasiswa Papua di Surabaya periode 16 Agustus - 21 Agustus 2019. Jurnal Commercium, 3(3), 25-37. Diakses dari https://ejournal.unesa.ac.id/index.php/Commercium/article/ view/36706

Launa. (2020). Sandiaga Uno dalam konstruksi media. Jurnal Penelitian Komunikasi, 23(1), 31-46. https://doi.org/10.20422/jpk.v23i1.656

Lestari, R. D. (2017). Quality news dan popular news sebagai trend pemberitaan media online (Studi deskriptif kualitatif trend pemberitaan quality news dan popular news pada media online nasional di Indonesia periode 2016). CHANNEL: Jurnal Komunikasi, 5(1), 83-94. https://doi.org/10.12928/channel.v5i1.6355

Lingga, M. A., \& Syam, H. M. (2018). Analisis framing pemberitaan Lesbian, Gay, Biseksual dan Transgender (LGBT) pada media online Republika.co.id dan Tempo.co. Jurnal Ilmiah Mahasiswa FISIP Unsyiah, 3(1), 1-12. Diakses dari http://jim.unsyiah.ac.id/ FISIP/article/view/6567 
Mansyur, S. A. (2020). Ideologi representasi Benny Wenda dalam media Bahasa Inggris Indonesia dan media luar. Seminar Internasional Riksa Bahasa, 867-876. Diakses dari http://proceedings.upi.edu/index.php/riksabahasa/article/view/953

Miles, M. B., Huberman, M. A., \& Saldana, J. (2020). Qualitative data analysis: a methods sourcebook (Utg. 4) Los Angeles. California: SAGE Publications.

Moleong, L. J. (2014). Metodologi penelitian kualitatif. Bandung: Remaja Rosdakarya.

Muslim. (2013). Konstruksi media tentang serangan Israel terhadap Lebanon. Jurnal Studi Komunikasi Dan Media, 17(1), 75-92. https://doi.org/10.31445/jskm.2013.170104

Presiden Republik Indonesia. Undang-Undang Republik Indonesia Nomor 42 Tahun 2008 tentang Pemilihan Umum Presiden dan Wakil Presiden. Lembaran Negara Republik Indonesia Tahun 2008 Nomor 176 (2008). Jakarta: https://www.dpr.go.id/dokjdih/ document/uu/UU_2008_42.pdf.

Putra, G. N. S., Legionosuko, T., \& Madjid, A. (2019). Strategi pemerintah Indonesia terhadap negara-negara anggota Melanesian Spearhead Group (MSG) dalam menghadapi propaganda Organisasi Papua Merdeka (OPM): Studi kasus Negara Republik Vanuatu. Jurnal Peperangan Asimetris, 5(2), 31-44. Diakses dari http://jurnalprodi.idu.ac.id/ index.php/PA/article/view/409

Rubiwati, E. (2018). Papua dalam media: Analisis framing pemberitaan otonomi khusus di Papua Barat. Jurnal Masyarakat \& Budaya, 20(3), 375-390. https://doi.org/10.14203/ jmb.v20i3.671

Sabir, A. (2018). Diplomasi publik Indonesia terhadap Vanuatu dalam upaya membendung gerakan separatisme Papua. Jurnal Hubungan Internasional, 11(1), 91. https://doi. org/10.20473/jhi.v11i1.8679

Sadarusalam, B. W.A., \& Hasan, K. (2019). Kontra propaganda Badan Nasional Penanggulangan Terorisme dalam menanggulangi perkembangan radikalisme di Indonesia. The Indonesian Jurnal Of Politics And Policy, 1(1), 74-82. Diakses dari https://journal.unsika.ac.id/ index.php/IJPP/article/view/1648

Santosa, R. (2016). Analisis framing pemberitaan Etnis Tionghoa dalam media online Republika di bulan Februari 2016. Journal E-Komunikasi, 4(1), 1-12. Diakses dari http:// publication.petra.ac.id/index.php/ilmu-komunikasi/article/view/4876

Tahir, R., Kusmanto, H., \& Amin, M. (2020). Propaganda politik hoaks dalam pemilihan Presiden tahun 2019. Perspektif, 9(2), 236-251. https://doi.org/10.31289/perspektif. v9i2.3458

Tempo.co. (2021). Tentang kami. Diakses January 21, 2021, dari https://www.tempo.co/about Widyaningsih, S. N., \& Lestari, R. D. (2020). Framing of online media news about Riots in Papua (Studies on www.detik.com and www.reuters.com in 2019). Journal Pekommas, 5(1), 81. https://doi.org/10.30818/jpkm.2020.2050109 